\title{
Беляева И.М.
}

\section{- СИСТЕМНОСТИ МЕР ПРЕДУПРЕХДЕНИЯ ЭКОЛОГИЧЕСКИХ ПРАВОНАРУШЕНИЙ И ПРЕСТУПЛЕНИЙ 1}

\section{Belyaeva I.M. ON THE CONSISTENCY OF MEASURES TO PREVENT ENVIRONMENTAL OFFENSES AND CRIMES}

В статье предлагаются пути закрепления системы мер профилактики и предупреждения административных правонарушений и преступлений в сфере охраны окружающей среды. Не фиксируясь на самих понятиях профилактики и предупреждения экологических правонарушений и преступлений, автор акцентирует внимание на необходимости законодательного решения данного вопроса на уровне соответствующего консолидированного закона субъекта Российской Федерации.

Ключевые слова: предупреждение преступности, предупреждение экологических правонарушений и преступлений.

The article proposes ways to consolidate the system of preventive measures and prevention of administrative offences and crimes in the field of environmental protection. Without fixing on the very concepts of prevention and prevention of environmental offences and crimes, the author focuses on the need for legislative solution of this issue at the level of the relevant consolidated law of the subject of the Russian Federation.

Keywords: crime prevention, prevention of environmental offenses and crimes.

Важнейшей задачей государственной политики является предупреждение преступлений и правонарушений, и эффективная реализация этой задачи не может не оказывать позитивного влияния на качественные и количественные характеристики преступности. Превенция преступлений и иных правонарушений схожа по своему содержанию и механизмам реализации, в связи с чем в данной работе мы позволим себе говорить о консолидированной системе предупредительных мер, направленных на сохранение окружающей среды.

Федеральный закон от 23.06.2016 г. № 182-ФЗ «Об основах системы профилактики правонарушений в Российской Федерации» в п. 13 ч. 1 ст. 6 закрепляет обеспечение экологической безопасности, охрану окружающей среды как одно из основных направлений профилактики правонарушений в Российской Федерации. Статья 5 этого закона к субъектам профилактики правонарушений относит:
1) федеральные органы исполнительной власти;

2) органы прокуратуры Российской Федерации;

3) следственные органы Следственного комитета Российской Федерации;

4) органы государственной власти субъектов Российской Федерации;

5) органы местного самоуправления.

Таким образом, каждый из перечисленных субъектов профилактики в пределах своих полномочий обязан осуществлять профилактическую деятельность в сфере охраны окружающей среды.

Было бы логично в «центральном» законе в сфере охраны окружающей среды - Федеральном законе от 10.01.2002 № 7-Ф3 (ред. от 09.03.2021) «Об охране окружающей среды» сформулировать не только нормы о государственном экологическом надзоре и общественном контроле в этой области, об установлении юридической ответственности за нарушение экологического законодательства,

Статья выполнена при финансовой поддержке РФФИ и Челябинской области (проект № 20-411740012) 
но и определить систему общесоциальных и специальных мер, направленных на профилактику и предупреждение экологических правонарушений и преступлений, но закон таких положений не содержит.

Поскольку правовое регулирование экологических правоотношений отнесено к совместному ведению Российской Федерации и ее субъектов, вопрос о профилактике и предупреждении правонарушений в данной сфере мог бы быть разрешен именно на уровне субъекта Федерации, что позволило бы учесть все существенные особенности региона, его экологическую специфику и выстроить действенную систему мер профилактики и предупреждения экологических правонарушений и преступлений.

Но здесь выявляется та же проблема, что и на федеральном уровне - если и есть в субъекте Федерации специальный консолидированный закон об охране окружающей среды (Экологический кодекс субъекта РФ), он также не содержит «программных» мер предупреждения экологических правонарушений.

В Челябинской области такой закон отсутствует, однако в соответствии со статьей 8.2 Федерального закона от 26.12.2008 № 294-Ф3 «О защите прав юридических лиц и индивидуальных предпринимателей при осуществлении государственного контроля (надзора) и муниципального контроля", Постановлением Правительства Российской Федерации от 26.12.2018 № 1680 «Об утверждении общих требований к организации и осуществлению органами государственного контроля (надзора), органами муниципального контроля мероприятий по профилактике нарушений обязательных требований, требований, установленных муниципальными правовыми актами» приказом министра экологии Челябинской области от 16.12.2020 № 845 утверждена Программа профилактики нарушений обязательных требований Министерства экологии Челябинской области при осуществлении регионального государственного экологического надзора на 2021-2023 годы, которая содержит элементы предупреждения административных правонарушений и преступлений в сфере экологических отношений. Стоит отметить, что такие программы разрабатываются и реализуются на постоянной основе, размещаются на сайте Министерства экологии Челябинской области, результаты исполнения Программы за определенный период публикуются Министерством, проводится анализ причин и условий совершения правонарушений и преступлений, обобщается правоприменительная практика.

Серьезным инструментом профилактики экологических правонарушений и преступлений стал Региональный экологический стандарт Челябинской области, утвержденный Протоколом заседания Координационного совета при Губернаторе Челябинской области по вопросам экологии от 02.12.2020 года. Но нужно понимать, что хоть Стандарт и определяет четыре ключевых направления для обеспечения экологической безопасности и улучшения качества окружающей среды в регионе (экология производства, экология человека, экологический бизнес, экология природной среды), его применение является добровольным.

То есть региональные власти активно работают над улучшением экологической ситуации, формируя отдельные элементы системы профилактики и предупреждения экологических правонарушений и преступлений, решая тактические задачи. Но вот стратегически сама система этих мер законодательно не сформирована, что, на наш взгляд, создает фрагментарную картину превенции в данной сфере без четких взаимосвязей между субъектами профилактики.

Было бы логичным шагом, учитывая специфику нашего региона, включить в региональный закон об охране окружающей среды (при его разработке) нормы о профилактике и предупреждении экологических правонарушений и преступлений, четко зафиксировав систему мер превенции и ее субъектов, указав орган государственной власти, координирующий данную деятельность.

Как отмечает Д.Н. Джунусова, «основой общего предупреждения экологической преступности должны являться меры, направленные на укрепление экономики, обеспечение населения рабочими местами, повышение социально-экономического уровня жизни населения формирование в обществе позитивного нравственного климата. К мерам общей профилактики относятся также формирование и последовательная реализация общегосударственной экологической политики; обеспечение стабильности и оптимизация деятельности системы органов государственного экологического контроля, препятствующие возникновению и действию коррупционных схем; совершенствование действующего уголовного, административного и экологического законодательства; установление обязательности проведения криминоло-
57

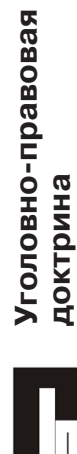


гической экспертизы принимаемых нормативных актов в данной сфере; повышение уровня общественного эколого-правового сознания населения»[1].

А.В. Балобеев, опираясь на результаты изучения теоретической базы, выделяет «ряд следующих основных направлений общих мер предупреждения преступного загрязнения природной среды: 1) правовые меры, связанные с совершенствованием уголовного и экологического законодательства; 2) социально-экономические меры, связанные с повышением благосостояния населения, с предоставлением льгот, направленных на поддержку предприятий, добросовестно занимающихся очисткой вредных выбросов в окружающую среду; 3) меры технологического характера, связанные, в частности, с модернизацией и развитием промышленности, оказывающей интенсивное воздействие на окружающую природную среду, и внедрением оптимальных современных технологий, призванных снизить вредное воздействие на атмосферу, поверхностные и подземные воды; 4) культурно-воспитательные меры, направленные на развитие экологическоправовой культуры населения; 5) меры, связанные с социально-правовым контролем, в том числе осуществляемом посредством проверок объектов, оказывающих интенсивное воздействие на окружающую природную среду»[2].

Полагаем, сюда же можно отнести экологическое образование, адекватное информирование населения об экологическом состоянии места проживания, стимулирование экономических субъектов к ведению деятельности в соответствии с экологическими нормами и нормативами, вовлечение всё большей части населения в «зеленые» проекты, осознанному бережному отношению к окружающей среде.

Специальная же превенция, на наш взгляд, должна быть очень четко выстроена с точки зрения субъектов профилактики, единого центра координации в лице регионального министерства (управления) экологии.

Пилотными проектами реализации специальной превенции и координации этой деятельности могут стать региональные экологические кодексы, законы субъекта Федерации об охране окружающей среды, экологические стандарты.

\section{Литература}

1. Джунусова Д.Н. Экологическая преступность и ответственность за экологические преступления: монография. - Российская академия естествознания, 2012 // https://www.monographies.ru/ru/book/section?id=5488

2. Балобеев А.В. Совершенствование мер предупреждения преступных деяний, загрязняющих природную среду и ее компоненты // Вестник ВосточноСибирского института МВД России. - 2020. - № 3 (94). - С. 58-59.

\section{References}

1. Dzhunusova D.N. Jekologicheskaja prestupnost' i otvetstvennost'za jekologicheskie prestuplenija: monografija. - Rossijskaja akademija estestvoznanija, 2012 // https://www.monographies.ru/ru/book/section?id=5488

2. Balobeev A.V. Sovershenstvovanie mer preduprezhdenija prestupnyh dejanij, zagrjaznjajushhih prirodnuju sredu i ee komponenty // Vestnik Vostochno-Sibirskogo instituta MVD Rossii. - 2020. - № 3 (94). - p. 58-59.

БЕЛЯЕВА Ирина Михайловна, кандидат юридических наук, доцент, заведующий кафедрой уголовного и уголовно-исполнительного права, криминологии, Южно-Уральский государственный университет (национальный исследовательский университет). 454080, г. Челябинск, пр. им. В.И. Ленина, 76. E-mail: beliaevaim@susu.ru

Belyaeva Irina Mikhailovna, Candidate of Sciences (Law), associate, Head Professor of Department of Criminal and Penal Enforcement Law, Criminology, South Ural State University (National Research University). 454080, Chelyabinsk, V.I. Lenin Ave., 76. E-mail: beliaevaim@susu.ru 